\title{
Regional variations in mortality from ischaemic heart and cerebrovascular disease in Britain
}

\author{
MARY FULTON, W. ADAMS, W. LUTZ, AND M. F. OLIVER \\ From the Departments of Community Medicine and Medicine, and the Medical Computing and \\ Statistics Group, University of Edinburgh
}

SUMMARY In middle-aged men and women, mortality from ischaemic heart disease and cerebrovascular disease is highest in the north and west of Britain. The worst region is West Central Scotland. Statistical analysis using a linear logistic model shows that the differences between the regions are significant and the yearly fluctuation in numbers of deaths contributes little to the overall variation.

Within Britain there are large variations in mortality from ischaemic heart disease and stroke. While differences in mortality from cardiovascular diseases have been reported in the county boroughs of England and Wales (Crawford et al., 1968) and more widely throughout the country by Howe (1970), we wish to reappraise these by applying new methods of analysis and assessing their importance in statistical terms.

\section{Methods}

The numbers of deaths which form the basic data of this paper were obtained from the Registrar General's Statistical Reviews of England and Wales and the Annual Reports of the Registrar General for Scotland. The age groups chosen for study were 35 to 44,45 to 54 , and 55 to 64 for men and women. At younger ages the numbers of deaths were too small for analysis while at older ages the accuracy of death certification is less satisfactory (General Register Office, 1966; Alderson and Meade, 1967).

The figures were extracted for each year from 1969 to 1973, making a total 5-year period. The 1971 census (the central year of the period) was used as the source of population data in the calculation of rates.

The following diagnostic groups were used: (a) all causes of death, (b) ischaemic heart disease (IHD) (ICD 410-414), (c) cerebrovascular disease (CVD) (ICD 430-438), (d) malignant neoplasms of trachea, bronchus, and lung (ICD 162).

The 8th revision of the International Classification of Disease (ICD) was in force throughout the period of the study.

Received for publication 20 April 1977
England and Wales were subdivided into the 9 standard regions described in the publications of the Office of Population Censuses and Surveys (Registrar General's Statistical Review of England and Wales, 1969). In Scotland 5 regions were chosen based on the Registrar General's geographical divisions (Annual Report of the Registrar General for Scotland, 1969). Regional boundaries have the disadvantage that they have developed for historical and political reasons and, therefore, do not necessary take epidemiological characteristics into account. This study was made before the new regional structure was introduced in 1974.

\section{Results}

Table 1 shows the study populations in each region. South Scotland has the smallest population followed

Table 11971 census population in thousands in the regions of England and Wales and Scotland

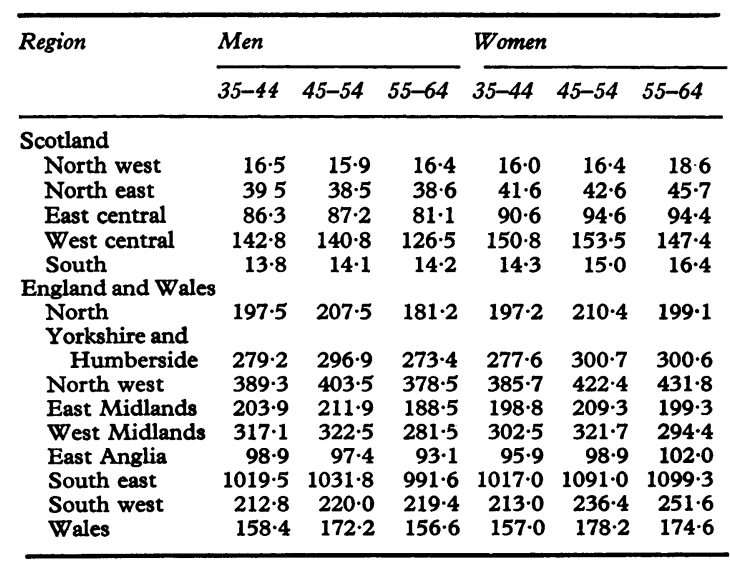


by North West Scotland. These regions were not merged with neighbouring ones as they have characteristics of population and topography different from adjacent regions. The largest region is South East England which includes London.
Tables 2 to 5 give the age and sex specific rates for all causes of death, ischaemic heart disease, cerebrovascular disease, and malignant neoplasms of trachea, bronchus, and lung. Table 6 presents for comparison the death rates for all remaining

Table 2 All causes of death: observed death rates per 100000 (averaged over 1969 to 1973)

\begin{tabular}{|c|c|c|c|c|c|c|c|c|c|c|c|c|c|c|}
\hline \multirow[b]{2}{*}{ Age } & \multicolumn{5}{|c|}{ Scotland } & \multicolumn{9}{|c|}{ England and Wales } \\
\hline & $\begin{array}{l}\text { North } \\
\text { west }\end{array}$ & $\begin{array}{l}\text { North } \\
\text { east }\end{array}$ & $\begin{array}{l}\text { East } \\
\text { central }\end{array}$ & $\begin{array}{l}\text { West } \\
\text { central }\end{array}$ & South & North & $\begin{array}{l}\text { Yorkshire } \\
\text { and } \\
\text { Humberside }\end{array}$ & $\begin{array}{l}\text { North } \\
\text { west }\end{array}$ & $\begin{array}{l}\text { East } \\
\text { Midlands }\end{array}$ & $\begin{array}{l}\text { West } \\
\text { Midlands }\end{array}$ & $\begin{array}{l}\text { East } \\
\text { Anglia }\end{array}$ & $\begin{array}{l}\text { South } \\
\text { east }\end{array}$ & $\begin{array}{l}\text { South } \\
\text { west }\end{array}$ & Wales \\
\hline $\begin{array}{l}\text { Mon } \\
35-44 \\
45-54 \\
55-64 \\
\text { Women }\end{array}$ & $\begin{array}{r}323 \\
871 \\
2140\end{array}$ & $\begin{array}{r}245 \\
714 \\
2087\end{array}$ & $\begin{array}{r}272 \\
821 \\
2264\end{array}$ & $\begin{array}{r}323 \\
998 \\
2654\end{array}$ & $\begin{array}{r}254 \\
747 \\
2180\end{array}$ & $\begin{array}{r}268 \\
850 \\
2326\end{array}$ & $\begin{array}{r}253 \\
768 \\
2185\end{array}$ & $\begin{array}{r}275 \\
866 \\
2372\end{array}$ & $\begin{array}{r}227 \\
685 \\
1960\end{array}$ & $\begin{array}{r}233 \\
771 \\
2157\end{array}$ & $\begin{array}{r}187 \\
587 \\
1702\end{array}$ & $\begin{array}{r}204 \\
644 \\
1854\end{array}$ & $\begin{array}{r}205 \\
650 \\
1873\end{array}$ & $\begin{array}{r}263 \\
813 \\
2329\end{array}$ \\
\hline $\begin{array}{l}35-44 \\
45-54 \\
55-64\end{array}$ & $\begin{array}{r}170 \\
482 \\
1085\end{array}$ & $\begin{array}{r}164 \\
470 \\
1081\end{array}$ & $\begin{array}{r}186 \\
531 \\
1191\end{array}$ & $\begin{array}{r}216 \\
602 \\
1370\end{array}$ & $\begin{array}{r}176 \\
529 \\
1191\end{array}$ & $\begin{array}{r}183 \\
503 \\
1144\end{array}$ & $\begin{array}{r}175 \\
462 \\
1094\end{array}$ & $\begin{array}{r}182 \\
505 \\
1185\end{array}$ & $\begin{array}{r}158 \\
438 \\
1006\end{array}$ & $\begin{array}{r}165 \\
432 \\
1035\end{array}$ & $\begin{array}{l}141 \\
379 \\
892\end{array}$ & $\begin{array}{l}151 \\
406 \\
932\end{array}$ & $\begin{array}{l}149 \\
402 \\
939\end{array}$ & $\begin{array}{r}178 \\
466 \\
1104\end{array}$ \\
\hline
\end{tabular}

Table 3 Ischaemic heart disease (ICD 410-414) death rates per 100000 : comparison of observed rates (averaged over 1969 to 1973) and estimated rates

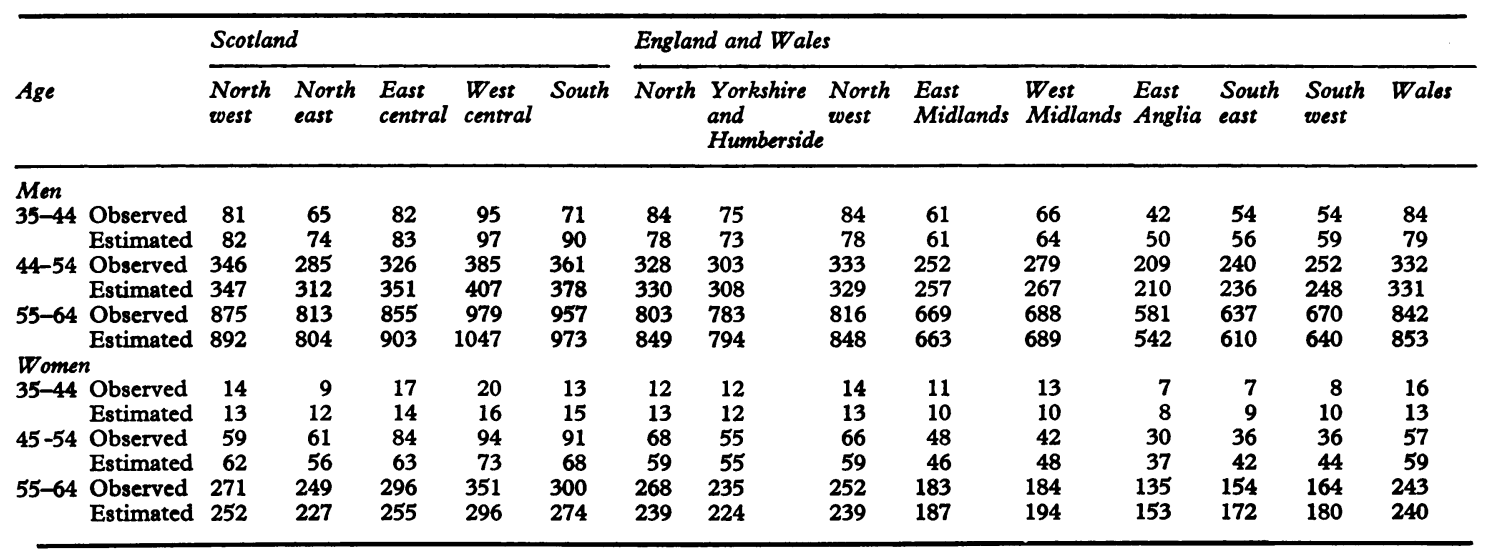

Table 4 Cerebrovascular disease (ICD 430-438) death rates per 100000 : comparison of observed rates (averaged over 1969 to 1973) and estimated rates

\begin{tabular}{|c|c|c|c|c|c|c|c|c|c|c|c|c|c|c|c|}
\hline \multirow[b]{2}{*}{ Age } & & \multicolumn{5}{|c|}{ Scotland } & \multicolumn{9}{|c|}{ England and Wales } \\
\hline & & $\begin{array}{l}\text { North } \\
\text { west }\end{array}$ & $\begin{array}{l}\text { North } \\
\text { east }\end{array}$ & $\begin{array}{l}\text { East } \\
\text { central }\end{array}$ & $\begin{array}{l}\text { West } \\
\text { central }\end{array}$ & South & North & $\begin{array}{l}\text { Yorkshire } \\
\text { and } \\
\text { Humberside }\end{array}$ & $\begin{array}{l}\text { North } \\
\text { west }\end{array}$ & $\begin{array}{l}\text { East } \\
\text { Midlands }\end{array}$ & $\begin{array}{l}\text { West } \\
\text { Midlands }\end{array}$ & $\begin{array}{l}\text { East } \\
\text { Anglia }\end{array}$ & $\begin{array}{l}\text { South } \\
\text { east }\end{array}$ & $\begin{array}{l}\text { South } \\
\text { west }\end{array}$ & Wales \\
\hline $\begin{array}{l}\text { Men } \\
35-44 \\
45-54 \\
55-64\end{array}$ & $\begin{array}{l}\text { Observed } \\
\text { Estimated } \\
\text { Observed } \\
\text { Estimated } \\
\text { Observed } \\
\text { Estimated }\end{array}$ & $\begin{array}{r}17 \\
15 \\
60 \\
57 \\
202 \\
202\end{array}$ & $\begin{array}{r}10 \\
13 \\
38 \\
48 \\
174 \\
173\end{array}$ & $\begin{array}{r}16 \\
15 \\
47 \\
55 \\
197 \\
197\end{array}$ & $\begin{array}{r}18 \\
17 \\
63 \\
64 \\
223 \\
230\end{array}$ & $\begin{array}{r}28 \\
17 \\
47 \\
62 \\
197 \\
223\end{array}$ & $\begin{array}{r}14 \\
14 \\
53 \\
52 \\
191 \\
187\end{array}$ & $\begin{array}{r}12 \\
12 \\
43 \\
44 \\
165 \\
158\end{array}$ & $\begin{array}{r}15 \\
14 \\
52 \\
51 \\
185 \\
184\end{array}$ & $\begin{array}{r}12 \\
11 \\
43 \\
42 \\
158 \\
151\end{array}$ & $\begin{array}{r}12 \\
12 \\
48 \\
46 \\
168 \\
165\end{array}$ & $\begin{array}{r}9 \\
10 \\
32 \\
36 \\
128 \\
129\end{array}$ & $\begin{array}{r}10 \\
9 \\
36 \\
35 \\
121 \\
124\end{array}$ & $\begin{array}{r}8 \\
11 \\
42 \\
42 \\
136 \\
140\end{array}$ & $\begin{array}{r}13 \\
14 \\
54 \\
51 \\
190 \\
183\end{array}$ \\
\hline $\begin{array}{l}\text { Womer } \\
35-44 \\
45-54 \\
55-64\end{array}$ & $\begin{array}{l}n \\
\text { Observed } \\
\text { Estimated } \\
\text { Observed } \\
\text { Estimated } \\
\text { Observed } \\
\text { Estimated }\end{array}$ & $\begin{array}{r}13 \\
16 \\
51 \\
52 \\
151 \\
153\end{array}$ & $\begin{array}{r}12 \\
14 \\
48 \\
44 \\
140 \\
131\end{array}$ & $\begin{array}{r}15 \\
15 \\
56 \\
51 \\
150 \\
150\end{array}$ & $\begin{array}{r}16 \\
18 \\
62 \\
59 \\
179 \\
174\end{array}$ & $\begin{array}{r}22 \\
18 \\
59 \\
57 \\
190 \\
169\end{array}$ & $\begin{array}{r}15 \\
15 \\
49 \\
48 \\
137 \\
142\end{array}$ & $\begin{array}{r}13 \\
12 \\
36 \\
40 \\
118 \\
120\end{array}$ & $\begin{array}{r}15 \\
14 \\
47 \\
47 \\
136 \\
139\end{array}$ & $\begin{array}{r}12 \\
12 \\
39 \\
39 \\
106 \\
114\end{array}$ & $\begin{array}{r}13 \\
13 \\
41 \\
42 \\
122 \\
125\end{array}$ & $\begin{array}{r}10 \\
10 \\
33 \\
33 \\
103 \\
98\end{array}$ & $\begin{array}{l}10 \\
10 \\
33 \\
32 \\
94 \\
94\end{array}$ & $\begin{array}{r}11 \\
12 \\
36 \\
39 \\
132 \\
114\end{array}$ & $\begin{array}{r}12 \\
14 \\
44 \\
47 \\
135 \\
139\end{array}$ \\
\hline
\end{tabular}


causes (that is excluding those for ischaemic heart disease, cerebrovascular disease, and malignant neoplasms of trachea, bronchus, and lung). Some of these results are illustrated in the Figure.

\section{Statistical commentary}

The method of statistical analysis used is that of the 'linear logistic model' (Nelder and Wedderburn, 1972) which considers $P$, the probability of dying from a disease for given age, sex, and region, to be a function of these factors and any other factors we may wish to consider. An analysis of variance approach to this type of data is given by ElShaarawi et al. (1976).

To establish whether the yearly fluctuations in the observed deaths were unduly pronounced, the first linear model tried included the factors age, sex, region, and year. The results of this analysis convincingly showed that the annual fluctuations in the data contributed a statistically insignificant amount to the overall variations, the main contributions to which were age, sex, and region. For all further analysis, therefore, the average number of deaths, expressed as age and sex specific death rates per 100000 , for the 5-year period 1969 to 1973, was used.

The reduced linear logistic model (that is using the average 5-yearly age-sex specific death rates per region) was fitted separately for the disease categories ischaemic heart disease, cerebrovascular disease, and malignant neoplasms of trachea, bronchus, and lung. The factors included were age, sex and interaction ${ }^{1}$ of age and sex, and region. The results are shown in Tables 3,4 , and 5 where the estimated values calculated from the logistic model are compared with the average death rate per 100000 over the 5 -year period. The comparison is adequate and in parts astonishingly close especially as the model only requires 18 degrees of freedom out of the total of 83 degrees of freedom. This strongly suggests that the combined effect of 4 factors, namely age, sex, age-sex interaction, and

'An 'interaction' variable allows for some combined and interrelated effect due to 2 variables over and above the effect of each of the variables considered separately.

Table 5 Malignant neoplasms of trachea, bronchus, and lung (ICD 162); death rates per 100000 : comparison of observed rates (averaged over 1969 to 1973) and estimated rates

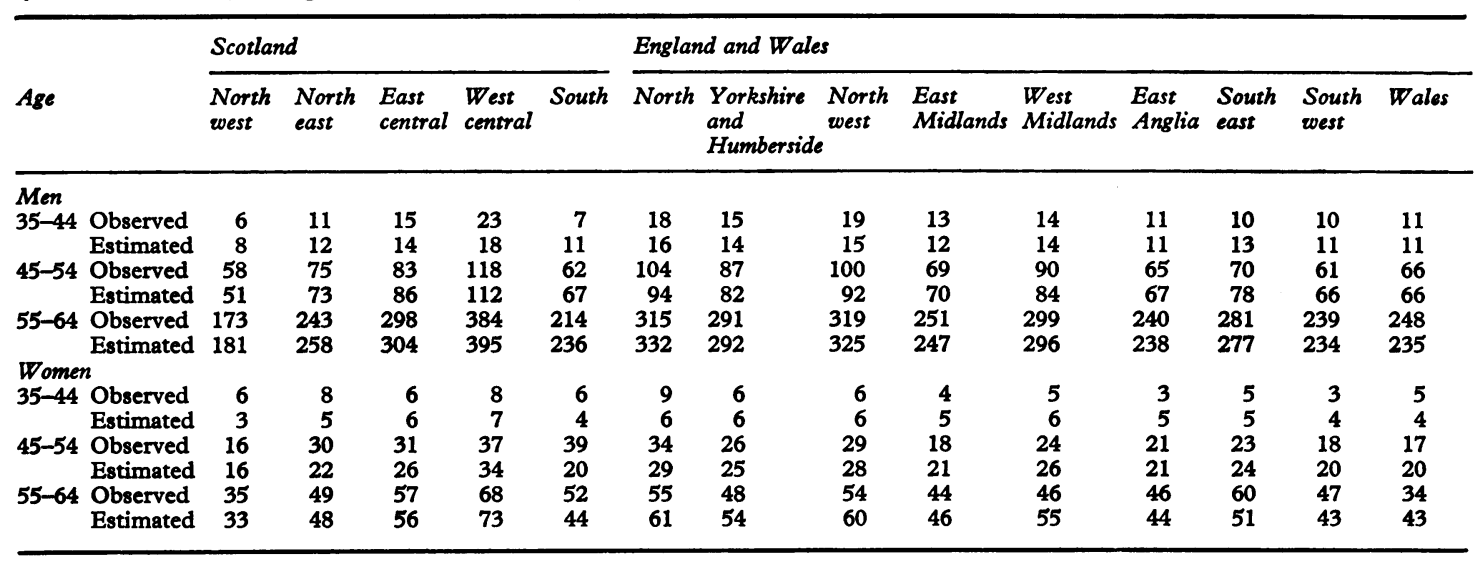

Table 6 All other causes of death (excluding ischaemic heart disease, cerebrovascular disease, and malignant neoplasms of trachea, bronchus, and lung) : observed death rates per 100000 (averaged over 1969 to 1973)

\begin{tabular}{|c|c|c|c|c|c|c|c|c|c|c|c|c|c|c|}
\hline \multirow[b]{2}{*}{ Age } & \multicolumn{5}{|c|}{ Scotland } & \multicolumn{9}{|c|}{ England and Wales } \\
\hline & $\begin{array}{l}\text { North } \\
\text { west }\end{array}$ & $\begin{array}{l}\text { North } \\
\text { east }\end{array}$ & $\begin{array}{l}\text { East } \\
\text { central }\end{array}$ & $\begin{array}{l}\text { West } \\
\text { central }\end{array}$ & South & North & $\begin{array}{l}\text { Yorkshire } \\
\text { and } \\
\text { Humberside }\end{array}$ & $\begin{array}{l}\text { North } \\
\text { west }\end{array}$ & $\begin{array}{l}\text { East } \\
\text { Midlands }\end{array}$ & $\begin{array}{l}\text { West } \\
\text { Midlands }\end{array}$ & $\begin{array}{l}\text { East } \\
\text { Anglia }\end{array}$ & $\begin{array}{l}\text { South } \\
\text { east }\end{array}$ & $\begin{array}{l}\text { South } \\
\text { west }\end{array}$ & Wales \\
\hline $\begin{array}{l}\text { Men } \\
35-44 \\
45-54 \\
55-64 \\
\text { Women }\end{array}$ & $\begin{array}{l}219 \\
407 \\
890\end{array}$ & $\begin{array}{l}159 \\
317 \\
856\end{array}$ & $\begin{array}{l}158 \\
365 \\
915\end{array}$ & $\begin{array}{r}186 \\
431 \\
1068\end{array}$ & $\begin{array}{l}148 \\
277 \\
812\end{array}$ & $\begin{array}{r}152 \\
365 \\
1017\end{array}$ & $\begin{array}{l}151 \\
335 \\
945\end{array}$ & $\begin{array}{r}158 \\
382 \\
1052\end{array}$ & $\begin{array}{l}140 \\
321 \\
883\end{array}$ & $\begin{array}{r}141 \\
354 \\
1003\end{array}$ & $\begin{array}{l}125 \\
281 \\
754\end{array}$ & $\begin{array}{l}131 \\
298 \\
815\end{array}$ & $\begin{array}{l}133 \\
296 \\
828\end{array}$ & $\begin{array}{r}155 \\
361 \\
1049\end{array}$ \\
\hline $\begin{array}{l}35-44 \\
45-54 \\
55-64\end{array}$ & $\begin{array}{l}138 \\
356 \\
629\end{array}$ & $\begin{array}{l}136 \\
332 \\
643\end{array}$ & $\begin{array}{l}148 \\
359 \\
686\end{array}$ & $\begin{array}{l}171 \\
409 \\
773\end{array}$ & $\begin{array}{l}135 \\
341 \\
649\end{array}$ & $\begin{array}{l}147 \\
352 \\
684\end{array}$ & $\begin{array}{l}144 \\
345 \\
692\end{array}$ & $\begin{array}{l}147 \\
363 \\
744\end{array}$ & $\begin{array}{l}131 \\
333 \\
673\end{array}$ & $\begin{array}{l}135 \\
325 \\
683\end{array}$ & $\begin{array}{l}122 \\
295 \\
608\end{array}$ & $\begin{array}{l}128 \\
313 \\
625\end{array}$ & $\begin{array}{l}127 \\
311 \\
596\end{array}$ & $\begin{array}{l}144 \\
348 \\
692\end{array}$ \\
\hline
\end{tabular}



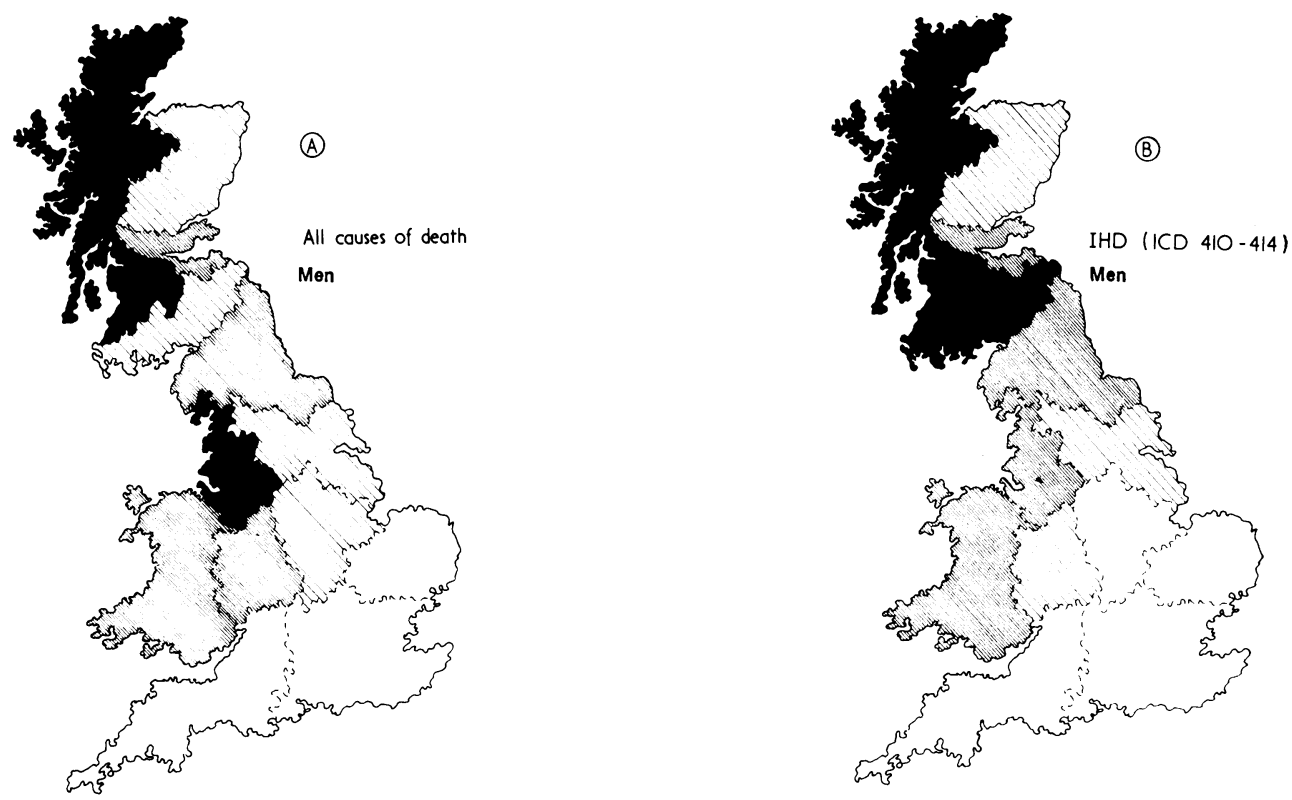

High quarter

3 rd quarter

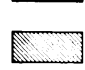

2nd quarter
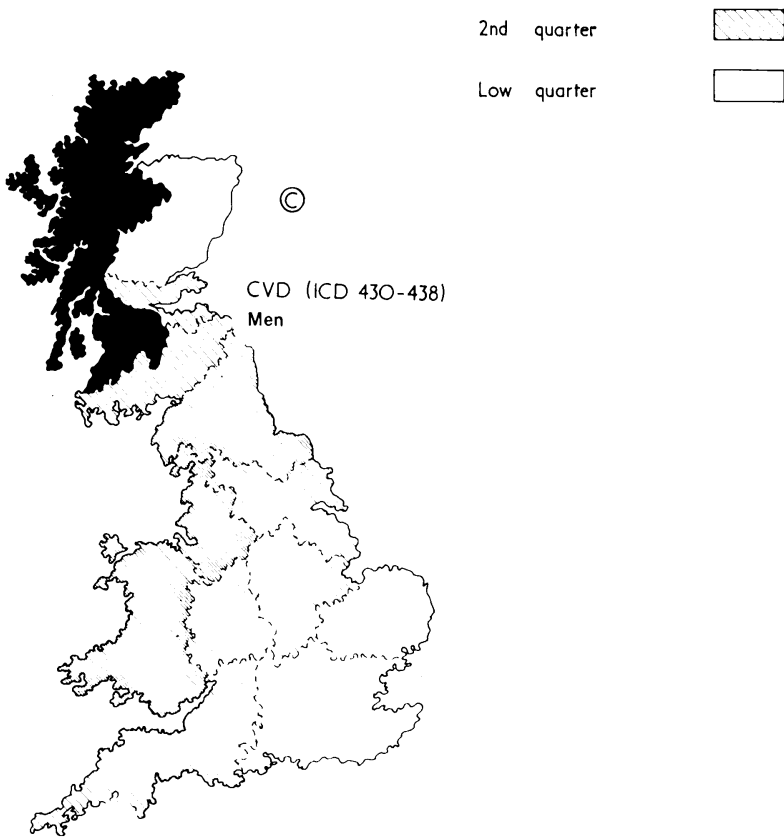

Low quarter

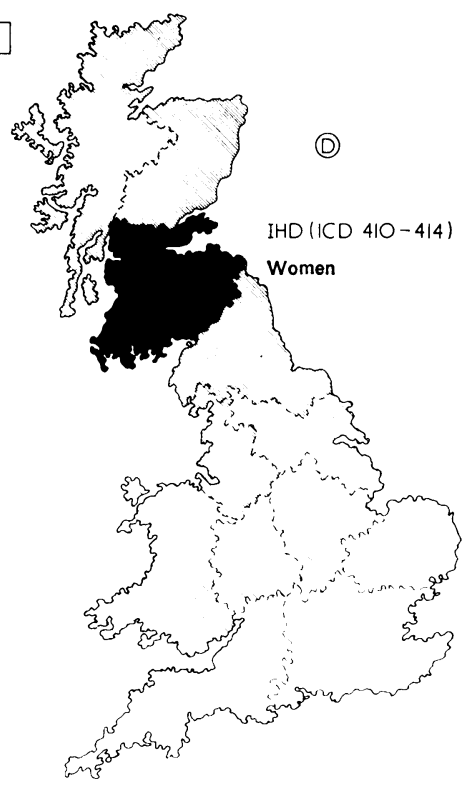

Fig. Death rates per 100000 at ages 45 to 54 in the regions of England and Wales and Scotland. The shading has been decided on the basis of division into quartiles in so far as this is possible with 14 regions. (A) All causes of death, men; (B) ischaemic heart disease (ICD 410-414), men; (C) cerebrovascular disease (ICD 430-438), men; (D) ischaemic heart disease (ICD 410-414), women. 
Table 7 Analysis of deviance

\begin{tabular}{|c|c|c|c|c|c|c|}
\hline \multirow[t]{2}{*}{ Source of variation } & \multirow{2}{*}{$\begin{array}{l}\text { Degrees of } \\
\text { freedom }\end{array}$} & \multicolumn{3}{|l|}{ Deviance } & \multirow{2}{*}{$\begin{array}{l}95 \text { per cent } \\
\text { critical value }\end{array}$} & \multirow{2}{*}{$\begin{array}{l}99.9 \text { per cent } \\
\text { critical value }\end{array}$} \\
\hline & & $\begin{array}{l}\text { Ischaemic heart } \\
\text { disease }\end{array}$ & $\begin{array}{l}\text { Cerebrovasiular } \\
\text { disease }\end{array}$ & Lung cancer & & \\
\hline $\begin{array}{l}\text { Age } \\
\text { Sex } \\
\text { Age-sex interaction } \\
\text { Region } \\
\text { Unaccounted remainder }\end{array}$ & $\begin{array}{r}2 \\
1 \\
2 \\
13 \\
65\end{array}$ & $\begin{array}{r}27390 \\
17114 \\
304 \\
1269 \\
163\end{array}$ & $\begin{array}{r}8569 \\
139 \\
31 \\
432 \\
32\end{array}$ & $\begin{array}{r}11312 \\
6716 \\
155 \\
253 \\
84\end{array}$ & $\begin{array}{r}6 \cdot 0 \\
3 \cdot 8 \\
6 \cdot 0 \\
22 \cdot 4 \\
84 \cdot 8\end{array}$ & $\begin{array}{r}13 \cdot 8 \\
10 \cdot 8 \\
13 \cdot 8 \\
34 \cdot 5 \\
106 \cdot 0\end{array}$ \\
\hline Overall & 83 & 46240 & 9203 & 18520 & - & - \\
\hline
\end{tabular}

the 'regional effect' explains nearly all the variation in the data. This is again shown in another way in Table 7.

From Table 7 it is immediately clear whether any of the 'effects' are statistically significant, at either the 95 per cent or 99.9 per cent levels, by comparing the value in the deviance ${ }^{1}$ column with the corresponding critical $\chi^{2}$ value; if the deviance exceeds the critical value then the effect is statistically significant at that level (Nelder and Wedderburn, 1972). It is clear that statistically the regional effect for all these disease categories cannot be explained by random variation. The regional effect is real and contributes to the variation in the death rates. In absolute terms, age and sex have more effect than the regions. But the regional effect may suggest aetiological factors not at present recognised and is the more important in terms of medical intervention.

By fitting a linear logistic model including 'region-age' and 'region-sex' interaction terms, some evidence is found that there is a greater regional effect (variation) for women with ischaemic heart disease but there is no indication that the regional effect is more pronounced for any one of the age groups for ischaemic heart disease. There is no indication that the regional effect is in any way more distinct for one of the sexes or for one of the age groups for cerebrovascular disease or lung cancer. However, these statistically significant results must be seen in relation to their practical effects. When these 'region-age' and 'region-sex' interaction terms were included in the linear logistic model and when this model was used to calculate estimated death rates, the improvement in estimated values was slight as compared with estimates from a model omitting these interaction terms. Present evidence, therefore, suggests that regional variation is only marginally changed when considering men compared with women or the younger with the older age group.

'The analysis of deviance can be considered as a generalisation of the analysis of variance. A definition is given by Nelder and Wedderburn (1972).
A similar analysis was undertaken to examine changes in regional effect with the disease category. Ischaemic heart disease and cerebrovascular disease have a very similar pattern of variation over the country, while lung cancer shows a different pattern. There is thus some evidence that the regional effect or variation is different for at least some diseases.

\section{Discussion}

The highest rates for ischaemic heart disease and cerebrovascular disease mortality are in the north and west of Britain. There are, in general, higher rates in the west compared to the east side of the country. The worst region is west central Scotland. Further north the rates tend to be lower. Most rates in the age-sex groups studied are substantially higher in Scotland than in the English regions. The problem of the very high mortality from ischaemic heart disease in Scotland has recently been emphasised by figures from the World Health Statistics Annual for 1972 (1975) which indicates that Scotland is second only to Finland in having the highest rates in the world for men aged 35 to 64 (359 per 100000 at age 45 to 54): this contrasts with England and Wales where the rates are appreciably lower (289 per 100000 at age 45 to 54).

Criticism has been directed at mortality data on the grounds of the inaccuracy of death certification. While some of this is justified, it is clear that the use of mortality statistics can given an overall picture of many diseases. The use of broad diagnostic categories such as ischaemic heart disease and cerebrovascular disease has been shown to reduce inaccuracy and the proportion of new facts found at necropsy is lower in the age groups below 65 (Reid and Rose, 1964; General Register Office, 1966; Alderson and Meade, 1967). There is at present no evidence to suggest that there are regional differences in death certification practice.

We do not propose to speculate about the reasons for the regional differences in mortality data.

Studies are needed to determine whether these 
differences apply also to morbidity data.

The implication of these findings should be heeded in the distribution of health service and research resources.

\section{References}

Alderson, M. R., and Meade, T. W. (1967). Accuracy of diagnosis on death certificates compared with that in hospital records. British Fournal of Preventive and Social Medicine, 21, 22-29.

Annual Report of the Registrar General for Scotland (1969). Part I-Mortality Statistics, p. 9.

Crawford, M. D., Gardner, M. J., and Morris, J. N. (1968). Mortality and hardness of local water supplies. Lancet, 1, 827-831.

El-Shaarawi, A. H., Cherry, W. H., Forbes, W. F., and Prentice, R. L. (1976). A statistical model for studying regional differences in observed mortality rates, and its application to Ontario during 1964-1968. Fournal of Chronic Diseases, 29, 311-330.

General Register Office (1966). Accuracy of certification of cause of death. Studies on Medical and Population Subjects No. 20. H.M.S.O., London.

Howe, G. M. (1970). National Atlas of Disease Mortality in the United Kingdom, 2nd ed. Nelson, London.

Nelder, J. A., and Wedderburn, R. W. M. (1972). Generalized linear models. Fournal of the Royal Statistical Society, Series A, 125, 370-384.

Registrar General's Statistical Review of England and Wales (1969). Part I Tables, Medical, p. xiii.

Reid, D. D., and Rose, G. A. (1964). Assessing the comparability of mortality statistics. British Medical fournal, 2, 1437-1439.

World Health Statistics Annual for 1972 (1975). Volume 1. World Health Organization, Geneva.

Requests for reprints to Dr M. F. Oliver, Department of Medicine, The Royal Infirmary, Edinburgh EH3 9YW. 